\title{
Indonesian Crisis Communication Response after Deliberate Forest Fires and Transboundary Haze
}

\author{
MOHAMMED FADEL ARANDAS \\ LOH YOKE LING \\ Southern University College, Malaysia
}

\begin{abstract}
The issue of deliberate forest fires that set illegally in Indonesia by plantation companies in their slashand-burn forests to clear lands for lucrative palm oil plantations and its caused transboundary haze became a hot issue for discussion. These fires have a negative influence on Indonesia and its neighbourhood countries, especially on their financial and human resources such as environment, economy, properties, and people. Using the right strategies in responding to any crisis determines the success of its management and coping with that crisis with minimal losses. This study aimed to examine the communication crisis response by Indonesia to this crisis by using image repair theory. Also, this study examined how image repair strategies were used by Indonesia. This study analysed the content of news stories from the website of the New Straits Times newspaper. The time frame of this study was from 2015 to 2019. A total of 87 news stories have pertained to Indonesian response, and 37 stories included image repair strategies. Among the strategies of image repair theory, corrective action strategy was the most dominant with $70 \%$, followed by $10.8 \%$ for each shift the blame and attack accuser. The least used strategies were mortification and simple denial with $5.4 \%$ and $2.7 \%$ respectively.
\end{abstract}

Keywords: Indonesia, crisis communication, image repair, transboundary haze, deliberate fires.

\section{INTRODUCTION}

The deliberate fires in Indonesia became a significant issue due to its association with global warming and climate change issues. The Indonesian forest fires are started illegally by plantation companies and farmers since it is cheaper than using the machinery to clear the lands. The Indonesian fires have devastated results on many Southeast Asian countries including Indonesia and its neighbourhood countries such as Malaysia, Singapore, Brunei and southern Thailand.

This transboundary haze pollution that blanketed those countries through the dry monsoon has several negative influences including ecology, declaring emergencies, shutting down schools, cancellation of several events, shutting down airports, and difficulties in mobility and productivity. Hence, angering the neighbours of Indonesia and causing some political tension, dispute, and diplomatic friction. However, it is believed that some of the involved culprit parties in carrying out the forest fires are Malaysian and Singaporean palm oil companies. Indonesia has implemented several efforts to settle this issue such as dispatching personnel to extinguish the fires, cloud seeding, arresting some of the culprits, and sealing some involved palm oil companies.

Most of the countries in this world are influenced by deliberate fires which are a very common problem. They cause a high insecurity sense within communities, straining and consuming several financial and human resources, endanger lives, and damage properties. Despite different attempts in reducing and tackling deliberate fires, they still largely 
ineffective due to the case-by-case approach executed to respond to these incidents (Bruenisholz, Wilson-Wilde, Ribaux \& Delémont, 2019).

Studying the communication of climate change became a significant research field. Stakeholders such as politicians, scientists, NGOs, or corporations are using the media including social media and the internet to mobilise support and provide information about this issue (Schäfer, 2012). The movement of communication of climate change beyond the issues of policy and science has opened up public discourse nature. Whereas the communicators seek to reach much more audiences, use more various forums, channels, a wider messengers range, and a number of various framings (Moser, 2010). Framing or describing a crisis may influence the evaluation of the public to the responsible for that crisis. It also provides useful insights to choose suitable strategies to respond to a crisis and reduce the damage occurred (An \& Gower, 2009; Cho \& Gower, 2006). The framing concept was applied widely in both political and mass communication (Arandas, Chang, Mohamad \& Idid, 2019).

\section{PROBLEM STATEMENT}

Understanding crises events is significant, especially by clarifying and understanding the role of communication processes in the meaning, beginning, managing, and resolution of crises (Sellnow, Seeger \& Ulmer, 2002). There is little known exists on the crisis communication response by Indonesia after the transboundary haze crisis. In order to fill this gap, this study went beyond the limited geographic borders by examining the image repair strategies used by Indonesia as covered by the Malaysian New Straits Times newspaper.

\section{RESEARCH QUESTIONS}

1. What image repair strategies did Indonesia use in its response to the transboundary haze crisis?

2. How image repair strategies were used by Indonesia in its response to the transboundary haze crisis?

\section{LITERATURE REVIEW}

\section{Air Pollution and Southeast Asia haze}

The most vulnerable to effects of climate change is developing countries since they have fewer financial, social, and technological resources to adapt. In developing countries, it is anticipated that climate change to have far-reaching impacts on sustainable development. Those countries have very various individual circumstances and the specific effects on climate change of any country depend on many factors including social, economic, political, geographical, and cultural situations (United Nations Framework Convention on Climate Change, 2007).

The pollution due to the transboundary haze is one of the major health threat that poses the main environmental issues to several Southeast Asian countries for decades. Several ASEAN region countries and their people including Indonesia, Malaysia, Singapore, Brunei, and Southern Thailand have experienced this severe pollution (Heilmann, 2015; Sunchindah, 2015; Tan et al., 2017). This smoky haze becomes worse with monsoonal winds and dry weather and causes a great deterioration in the air quality of Indonesia and its neighbourhood countries (Tan et al., 2017). The crisis of the pollution of transboundary haze was a large-scale burning and deliberate forest fires mainly in Indonesia. The source of the majority forest burning haze came from the Indonesian Kalimantan province and Sumatra 
Island (Sunchindah, 2015; Tan et al., 2017), and other minor haze came from both Malaysian Sarawak and Sabah states (Tan et al., 2017).

This seasonal man-made transboundary haze resulting from forest and land fires caused by clearing vegetation. These uncontrolled burning and deliberate fires are carried out by Indonesian farmers for plantation and agricultural development. It includes ground maintenance, cleaning, clearing land, draining of peatlands, and growing plantation especially oil palm and rubber (Heilmann, 2015; Sunchindah, 2015; Tan et al., 2017; Yusof, Azid, Samsudin \& Jamalani, 2017). The occurrence of this burning was since it is economically cheaper than other ways in clearing the lands. The absence of legal restrictions, weakness of enforcement regulations, and not having heavy penalties from the authorities have encouraged the people to burn the lands (Sunchindah, 2015).

Over the years, the issue of haze pollution in the ASEAN states became highly contentious, and it has its implications in regional politics. The attempts of ASEAN in addressing this environmental issue were intensified (Heilmann, 2015). Regional multilateral disputes and responsibilities were addressed on the issue of transboundary haze, and at the end, the measures of abatement were presented. In Peninsular Malaysia or West Malaysia, the first-ever reported case on haze issues was in the 1960s, but converting this controversial subject into scientific research was two decades later in 1980s (Yusof, Azid, Samsudin \& Jamalani, 2017).

The haze pollution has been acknowledged as a regional issue and got the concern of ASEAN in early 1985 after adopting the Conservation of Nature and Natural Resources Agreement which contained a reference to trans-frontier environmental influences and air pollution. Later, other agreements were followed with references to the issue of transboundary pollution, such as Kuala Lumpur Accord on Environment and Development in the 1990 and then Singapore Resolution on Environment and Development in 1992. Also, the first workshop in ASEAN Countries on Haze and Transboundary Pollution was held in 1992 in Balikpapan, Indonesia. Then, in 1994, the ASEAN held a ministerial meeting on the environment in that marked the beginnings of a visible effort in addressing the haze pollution problem (Heilmann, 2015).

Then, in 1997, there was another haze crisis due to the Indonesian forest fires that caused unprecedented damage in the ASEAN region which became an environmental catastrophe brink (Heilmann, 2015). The occurrence of severe haze and fire episodes in the years 1997 and 1998 has attracted both worldwide and regional and attention (Sunchindah, 2015). Then, in 2002, the Agreement on Transboundary Haze Pollution (AATHP) was signed by ASEAN. Yet, the non-interference in other states way has restrained relying on strong regional efforts to execute more effective action to combat and address the pollution of transboundary haze in Southeast Asia (Yusof, Azid, Samsudin \& Jamalani, 2017). Additionally, the ASEAN ministers of the environment have signed the ASEAN Agreement on Transboundary Haze Pollution (THPA) on 10 June 2002 in Kuala Lumpur (Heilmann, 2015).

In mid-2013 and 2015, there were severe transboundary haze issues for parts of Indonesia and its neighbourhood countries. Although more than a decade has passed since the signing of the ASEAN Haze Agreement, the problem of haze still recurs with serious consequences to health, tourism transportation, and other activities (Sunchindah, 2015). Then, on 16 September 2014, THPA agreement was ratified by the Indonesian lawmakers, and on 20 January 2015, Indonesia has deposited the instrument of ratification with the ASEAN Secretariat which makes it the last country that joint the agreement among the ASEAN. 
Yet, this ratification by Indonesia is not an instant game-changer. Also, the agreement's mechanisms are too weak in contributing much to haze pollution reduction in the region since designing the agreement built on non-intervention and state sovereignty principles. The coordination of action was not easy and it has proven cumbersome for regulating the pollution of transboundary haze through regional governance. Yet, several questions are raised beyond the reoccurrence of haze pollution, especially the ineffective framework of the governance and if that is likely to change after ratifying the agreement by Indonesia (Heilmann, 2015).

\section{Crisis and Communication Response}

Crises are affecting all countries around the world. Failing to control or manage the crisis will lead to a chain of crises (Fener \& Cevik, 2015). A crisis is inevitable and can occur at any place and time, and hit any organisation even in case of having awareness about it. This is true although if there is awareness about the crisis and there was an active attempt to prevent it. Crisis can be infliction on different organisational and individual levels or other aspects of crisis (Coombs, 2010; Harrison, 2005; Lee, Neeley \& Stewart, 2011; Selzer, 2013). All organisations are vulnerable to crisis and none of them is immune or exempt from it (Baker, 2001; Marra, 1992).

Crises are increasingly serious in social, political, economic, and environmental forces, and have the ability to make faster change than single phenomena. Crises have the possibility for causing harm and making systematic and extended disruption. Crises can reshape institutions, undermine economic stability, change the beliefs, make shifts in populations and demographics, and alter ecosystems. But, crises may be forced to constructive change, renewal, and growth (Sellnow \& Seeger, 2013).

Crises fix the spotlight on the people in power, break and make political careers, able to shape destinies of entities, and shake the bureaucratic orders. Crises happen in many forms and shapes starting from natural disasters, human-made incidents up to conflicts that influence the order of societies and peace negatively (Boin, Hart, Stern \& Sundelius, 2005). In natural disasters time, crisis communication is required since the crisis can be triggered by these disasters (Purworini, Purnamasari \& Hartuti, 2019). Crisis are diverse and they start from apparently localised and small events that interrupt the ability of an entity to achieve its objectives up to both international and national crisis that interrupt the political and social framework (Flynn, 2005). Those crises might also influence the public of an organisation, disturb its business, and threaten its survival (Zappala \& Carden, 2004). The type of crisis influence the interpretation of the audience of it (Ahmad, Ashari \& Samani, 2017).

Managing the crisis allows organisations to maintain the confidence of their stakeholders and mitigate damage (Ferguson, Wallace \& Chandler, 2012). It allows organisations to learn more from a crisis, get a quicker recovery, and accelerate the end of a crisis (Lee, Neeley \& Stewart, 2011). Crisis management is defined as the process of strategic planning for occurred negative event or crisis which aims to remove uncertainty and risk hence allows the organisation to control that situation (Fearn-Banks, 2011).

Crisis management is special procedures to solve the occurred problems because of crisis (Devlin, 2007). Crisis management is vital to the existence of an organisation and for ensuring its stability before perusing any growth objectives (Chong, 2004). Influential crisis management salvages the existence of organisations and protects their reputations (Tench \& Yeomans, 2006). Crisis management is an important matter since the bad management of crisis may destroy the reputation of an organisation, close it down, and undermine the years 
of work. The good management of the crisis is helpful to avoid the hazards and also enhance the reputation of an organisation in the long term (Morris \& Goldsworthy, 2008).

Crisis communication management is considered as public relations function that is increasingly significant to the fulfilment of organisational goals. Failing to fulfil the expectations and promises of an organisation causes negative consequences for it. The public of an organisation become sceptical about it after the crisis happen. The occurrence of ripple effects starts when an organisation faces a crisis that tarnishes its image (Wright, 2009). Good communication crisis allows the organisation to explain the event to its audiences, identify consequences, and give accurate information needed according to the needs of the affected parties (Saleh, 2019).

In the era of communication and information, understanding the played role by communication especially the internet is so crucial. In modern communications, the management of crisis public relations is one of the most crucial aspects. Effective management of crisis protects the organisations and their reputation, and also can save their existence. Preparedness is considered as the key to public relations crisis management. Effective crisis management should identify the crisis before its occurrence and can control it (Tench \& Yeomans, 2006).

In crisis communication, the public relations practitioners' role has expanded to match the wide notion of crisis. From this perspective, the role of public relations is a function of risk and crisis management that is responsible to maintain and develop response capacities and crisis management plans aimed at understanding the communication role in crisis (Seeger, Sellnow \& Ulmer, 2001). A situation of crisis communications might bring some negative, public attention cantering, and unusual false accusations about a vital issue to business sectors. In the communication perspective, the organisation has a problem in its crisis communication that should be solved if an issue becomes negative and the media has the story about it (Masduki, 2015). Considering the interaction between media and the sources of news is a pivotal issue (Shiang, Chibundu \& Wilson, 2020).

Understanding the effectiveness of crisis responses depends on analysing the situation of the crisis. The communication is influenced by the crisis and that situation influences the selected responses (Coombs, 1998). Effective crisis response is a competitive advantage as well as protects the reputation. Ineffective crisis response leads to a competitive disadvantage, and even may put the existence of an entity in risk (Garcia, 2006).

Effective management of crisis contains crisis communications that can reduce or eliminate the crisis and might improve the positive reputation of an organisation than what it was. The concern of public relations is about reputation especially to avoid a negative image and to build or improve the positive reputation. Additionally, crisis communications concern about dialogue between an organisation and its public regarding a negative event, and the tactics and strategies of dialogue designed to reduce the damage of an organisation's image. Proactive public relations programmes aim to build relationships with specific publics, and they can make them supportive of the organisation (Fearn-Banks, 2011).

Organisations are forced to respond when their images are threatened during crises. Those organisations attempt to reduce the negative publicity, return the stability of their economic, and regain the confidence of consumers (Cheng, Padgett $\&$ Parekh, 2013).

Maintain and strengthen the relationships an organisation and it's public or employing communication strategies might be the best protection for repairing and sustaining positive reputation in the long run (Ferguson, Wallace \& Chandler, 2018). 
Using crisis communication strategies and apology is related to restore or repair corporate reputation in the face of public (Greenberg \& Elliott, 2009). When the image of individuals or organisations is threatened by the crisis, they need to respond and defend their image, and present explanations, an excuse for behaviour, apologies, justifications, and rationalisations (Roberts, 2006). An image is a symbolic thought in the mind of people about a representation of specific objects or feelings (Wright, 2009).

In the past decades, the concepts of image, corporate reputation, standing, prestige, goodwill, esteem, and identity have a close relationship or were use synonymously (Wartick, 2002). The image was used as a synonym of other concepts such as attitude reputation, perception, belief, cognition, credibility, message, relationship, or communication. The image in public relations is the symbolic relationships between organisations and the public that occur through communication interaction. In psychology, image is considered as a cognition type (Grunig, 1993).

The term image "repair" become preferred over image "restoration", since "restoration" might mean restoring the image to its previous state. There should be an acceptance that this theory may not work at all (Benoit, 2000). Unfortunately, much of image restoration literature focuses on the efforts of organisations or individuals to save their reputations or face and instead of preventing the crisis they find themselves responding to them. When the smoke finally clears, organisations or individuals without clear-cut strategies of crisis communications are left struggling with ways of repairing sharp damage of their reputations (Baker, 2001; Marra, 1992).

The theory of image repair theory has five general strategies. (1) Denial: is the first strategy and has two variants which are: Simple denial through denying of performing the wrongful act and or; Shift the blame to another party or the "real" culprit. (2) Evading responsibility: is the second general strategy that contains four variants which are: Provocation by stating that the wrongful act was a response to another prior act; Defeasibility about the lack of control or information by the accused; Accident by indicating that the action was is a misfortune or a mishap and; Good intention by claiming to have meant well and good intentions. (3) Reducing offensiveness: is the third general strategy with six variants: Bolstering through mentioning on good deeds and qualities of the accused; Minimisation through reducing the seriousness or severity of the consequences; Differentiation by comparing the act with other worse or similar acts; Transcendence by discussing the more important ends or values of that act; Attack accuser by reducing the accuser's credibility and; Compensation by compensating the victim. (4) Corrective action: is the fourth general strategy through repair or prevent its recurrence. (5) Mortification: is the fifth general strategy by admitting the blame or, and or apologising and express remorse or regret (Benoit, 1997a; Benoit, 1997b; Benoit, 2006; Benoit, 2013).

\section{METHODOLOGY}

This study examined the coverage of the New Straits Times newspaper on the image repair strategies used by Indonesia after the crisis of deliberate forest fires and transboundary haze. The research design was both quantitative and qualitative content analysis due to the focus of this study. The use of content analysis method can be either qualitatively or quantitatively. It aims to build a model to describe a phenomenon in a conceptual manner (Elo \& Kyngäs, 2008). Qualitative and quantitative content analyses complement each other and combine both of them is primary to understand and determine the meanings of media texts and their effect on the public (Macnamara, 2005). 
The news stories were collected from New Straits Times (NST) website database through keyword search and from the link https://www.nst.com.my/hazecrisis. Originally, the search yielded a total of 87 news stories. Then, a total of 37 relevant news stories that included image repair strategies were analysed, while the other irrelevant stories were excluded from the analysis. The time frame of this study was from September 2015 until December 2019.

In this study, the coding schedule or coding sheet was the main instrument. To ensure the validity of this study, face validity was employed to assess the coding sheet. Additionally, to ensure the reliability, intercoder reliability between the two researchers was implemented. The unit of analysis in this study was each complete news story. After coding the news stories, a comparison between the coding sheets of the two researchers was employed to address any discrepancies. The overall intercoder reliability was 0.88 based on Holsti's (1969) reliability formula. The quantitative data analysis relied on the SPSS programme, while the qualitative analysis was human content analysis.

\section{RESULTS AND DISCUSSION}

The coverage of NST shows the volume of news stories that included image repair strategies. Table 1 presents a total of 37 news stories within five years. It can be seen that the year 2015 covered the most news stories that included image repair strategies with $43.2 \%$, followed by 2019 with 35.1\%. Then the year 2017 contained 10.8\% of stories, followed by 2016 and 2018 with $5.4 \%$ for each. The reasons beyond the high coverage on image repair strategies used by Indonesia in both 2015 and 2019 since the transboundary Indonesian haze of these two years was severer than the other three years. Hence, Indonesia needed more efforts in those two years to defend its tarnished image.

Table 1: Volume of stories of image repair strategies within five years

\begin{tabular}{lccc}
\hline & Year & Frequency & Percentage \\
\hline 2015 & 16 & 43.2 \\
2016 & 2 & 5.4 \\
2017 & 4 & 10.8 \\
2018 & 2 & 5.4 \\
2019 & 13 & 35.1 \\
Total & 37 & 100.0 \\
\hline
\end{tabular}

This section answers the first research question by examining the image repair strategies used by Indonesia in its communication response to the transboundary haze crisis. Table 2 presents the frequency of those image repair strategies as covered by NST. The coverage of NST revealed that all general image repair strategies were used except evasion of responsibility strategy. Out of 37 news stories, $70.3 \%$ of the stories were corrective action, followed by $10.8 \%$ for each shift the blame the variant of denial, and attack accuser the variant of reducing offensiveness of event. Finally, mortification strategy and simple denial the variant of denial figured $5.4 \%$ and $2.7 \%$ of news stories respectively. 
Table 2: Image repair strategies used by Indonesia

\begin{tabular}{|c|c|c|}
\hline Strategy & Frequency & Percentage \\
\hline Corrective action & 26 & 70.3 \\
\hline Shift the blame & 4 & 10.8 \\
\hline Attack accuser & 4 & 10.8 \\
\hline Mortification & 2 & 5.4 \\
\hline Simple denial & 1 & 2.7 \\
\hline Total & 37 & 100.0 \\
\hline
\end{tabular}

Moreover, this section answers the second research question by presenting several examples which shows how each strategy of image repair was used by Indonesia as covered by the New Straits Times newspaper. The use of image repair strategies was by Indonesian president Joko Widodo and other officials and representatives of his government. Corrective action strategy which was the most predominant contained several measures implemented by Indonesia in response to the transboundary haze crisis. Those measures included arresting and charging some of those who set the fires, deploying Indonesian personnel to extinguish the fire, vowing and assuring to prevent the setting the fire, and revoking the concessions of some involved companies. The following paragraphs elaborate about the measures taken by Indonesia:

\begin{abstract}
“Deputy Prime Minister Datuk Seri Dr Ahmad Zahid Hamidi said Malaysia welcomed the commitment shown by Indonesian president Joko Widodo to strengthen enforcement and fire-prevention measures, but lamented that the plans would take at least three years to see results" (NST, 4 Oct 2015). "The Indonesian government has given its assurance that the perennial haze problem will no longer be an issue next year" (NST, 2 Nov 2015).

"Indonesian police have detained seven people whose companies are allegedly connected with illegal agricultural fires that have cloaked Southeast Asia in a haze, in rare arrests over the annual smoke outbreaks" (NST, 17 Sep 2015).

"Indonesian President Joko "Jokowi" Widodo on Wednesday ordered an acceleration of efforts to extinguish forest fires whose thick smoky haze has affected parts of western Indonesia and neighbouring Malaysia and Singapore" (NST, 30 Sep 2015).

"Indonesian authorities have named more than 200 companies including oil palm, pulp producers and individual farmers as responsible for starting the fires and sealed their land holdings" (NST, 19 Sep 2015). "The Indonesian government has revoked concessions for 20 plantations in the republic to reduce slash and burn activities that could cause haze in the future" (NST, 4 Feb 2016).
\end{abstract}

Shift the blame the variant of denial strategy was also used by officials from the Indonesian government who tried to shift the blame to Malaysian and Singaporean companies. Indonesia tried to relieve the pressure on itself by accusing non-Indonesian of causing the transboundary haze that led to a dispute with its neighbouring countries. 
"It was reported that Indonesian Forestry Ministry secretary-general Hadi Daryanto had said Singapore and Malaysia should share part of the blame for causing the haze. Hadi had said Singapore and Malaysian palm oil companies had used the "slash and burn" method of clearing land, as it was cheap." (NST, 18 Sep 2015).

“Recently, Reuters quoted Indonesia's Environment Minister Siti Nurbaya Bakar as saying that there were four Malaysian companies out of at least 30 companies whose oil palm plantations in Indonesia were sealed off due to the fires. Siti Nurbaya reportedly named the firms as Sime Darby Plantation Bhd's Sime Indo Agro in West Kalimantan; IOI Corp Bhd's Sukses Karya Sawit; and TDM Bhd's Rafi Kamajaya Abadi." (NST, 19 Sep 2019).

Indonesia also tended to attack its Malaysian accusers about the source of the haze and dismissing their complaints. Attacking Malaysian accusers came by Indonesia's Environment Minister Siti Nurbaya Bakar who tended to reduce the credibility of its Malaysian accusers and refuting their claims.

"It was reported yesterday that Indonesia had dismissed complaints by Malaysians about hazardous smoke drifting from its forest fires across the border, saying blazes were also raging in parts of Malaysia and on Malaysianowned plantations in Indonesia" (NST, 14 Sep 2019).

"Indonesia's Environment Minister Siti Nurbaya Bakar on Friday said she felt Malaysia had not painted an objective picture of the frames, which have ripped through parts of Indonesia's Sumatra and Borneo islands for more than a month. Siti Nurbaya said while smog from fires in Indonesia may have crossed over to Malaysia, fires detected last week in the Malaysian state of Sarawak in Borneo and peninsular Malaysia also contributed to worsening air quality there. "I only asked that they (Malaysians) be objective and sequential in their data analysis," she told Reuters on Friday, responding to Kuala Lumpur's remarks that it was using recent data from ASEAN Specialised Meteorological Centre" (NST, 13 Sep 2019).

Additionally, mortification strategy was used by Indonesia through the apology of Indonesia from its neighbourhood countries. This strategy was used twice by the Indonesian President Joko Widodo and once Indonesian Parliament member.

\footnotetext{
"Indonesian president Joko Widodo today expressed regret to Malaysia over the haze which has blanketed the region over the past two months, said Prime Minister Datuk Seri Najib Razak"( NST, 11 Oct 2015).

"An Indonesian member of parliament has apologised for the bout of haze currently affecting the region...."I want to apologise to the Malaysian people for the haze. The fires that caused the haze were not started intentionally but were due to the drought affecting parts of Sumatra and Kalimantan," he told reporters on the sidelines of the event" (NST, 8 Sep 2015).
} 
Finally, simple denial, the variant of denial strategy was used once in a statement by the Indonesian Environmental Affairs and Forestry Minister Siti Nurbaya Bakar. She has claimed that the Haze originated from Sarawak and denied that the source of the haze in Malaysia is from Indonesia.

"It has been ascertained that until now, there has been no transboundary haze from Indonesia to neighbouring countries" (NST, 11 Sep 2019).

\section{CONCLUSION}

Currently, crises threaten individuals and organisation, and they can to ruin and tarnish their image and reputation, generate anger, and cause reputational damage (Strömbäck \& Kiousis, 2011; Tench \& Yeomans, 2006; Wright, 2009). The reputations of political figures are so valuable in political life. Thus, the strategies of image repair become substantial when the reputation of politicians is threatened due to the occurrence of crises (Chimbarange, Mukenge \& Kombe, 2013; Sheldon, 2006). The effectiveness of image repair strategy comes through using a persuasive response, selecting suitable strategies that match the charges and use these strategies in an effective way (Benoit \& Czerwinski, 1997).

Denial strategy is the first strategy of image repair theory. Both simple denial and shift the blame variants were used by Indonesia as covered by NST. The effectiveness of the denial strategy depends on its sustainability. In case of having evidence about the wrongdoing, then the wrongdoer needs to admit the charges or use corrective action (Benoit \& Anderson, 1996). However, there were several evidences that the source of the transboundary haze was Indonesia. Also, in several previous years, Indonesia itself could not deny that.

Attack accuser was the only variant of reducing offensiveness of event strategy which is the third strategy of image repair theory. Combining attacking accuser with another strategy such as denial makes them function best (Benoit \& Anderson, 1996). Reducing the credibility of the source of accusations might limit the damage to the image (Benoit, 1997a). Indonesia did not combine using attack accuser strategy with other strategies of image repair theory. Also, Indonesia tended to reduce the credibility of its Malaysian accusers but the Malaysian accusations were based on evidence.

Corrective action is the fourth strategy of image repair theory. This strategy focuses on a promise for repairing or preventing the recurrence of the problem (Benoit, 1997a). This strategy is essential in settling dust on various issues (Chimbarange, Mukenge \& Kombe, 2013). The use of this strategy works well with mortification, and the defence that includes both of these strategies is considered as a well-designed one (Benoit, 2014; Brinson \& Benoit, 1996). Several news stories stated the promises of Indonesia to stop the haze for example:

"The Indonesian government has given its assurance that the perennial haze problem will no longer be an issue next year" (NST, 2 Nov 2015). "Indonesia repeatedly vows to stop the fires but each year they return"( NST, 26 Aug 2016). "The head of Indonesia's Peatland Restoration Agency told a conference in May there would be "no more haze going to the neighbours" (NST, 25 Jul 2017). 
Based on this argument, failing to stop the reoccurrence of this crisis and not fulfilling the promises of Indonesia on this issue has weakened the use of its corrective action effort. Additionally, none of the corrective action strategies was combined with any mortification strategy to boost the position of the Indonesian defence.

Mortification strategy is the fifth strategy of image repair theory. The people often admire wrongdoers that have the courage for accepting the blame for their actions. Definitely, the people do not admire the offensive act but the forthright and confession by wrongdoers. Also, people do not appreciate the boasting by the wrongdoers but their remorse. Apologising and confessing the wrongdoing is difficult for politicians than other people. The difficulty in using mortification by politicians comes due to the loath in admitting mistakes. Although people are not infallible from doing mistakes politicians are loath to create an impression that they committed a mistake since other political actors might not be encouraged to corporate with those that appeared as error-prone (Benoit, 1997a). Additionally, the effectiveness of mortification and corrective action strategies are more than others (Benoit \& Drew, 1997).

The use of mortification strategy was very little, which came in line with the argument above and reflected that the use of apology is more difficult by politicians than other people. Hence, the use of mortification by Indonesia supposed to be much more than what it has been reported since its appropriateness and effectiveness are much more than many other image repair strategies.

\section{BIODATA}

Mohammed Fadel Arandas is an Assistant Professor in the Department of Journalism and Communication Studies, Faculty of Humanities and Social Sciences, Southern University College. His area of interest includes public relations, crisis communication, and media framing. Email: arandas@sc.edu.my

Loh Yoke Ling is an Assistant Professor and Head of the Department of Journalism and Communication Studies, Faculty of Humanities and Social Sciences, Southern University College. Her area of specialization is in broadcasting, documentary, and media literacy. Email: ylloh@sc.edu.my 


\section{REFERENCES}

Ahmad, D. A. M. A., Ashari, N. M., \& Samani, M. C. (2017). Effect of rational and emotional framing on highly involved audience in severe crisis situation: An experimental study on MH370. Jurnal Komunikasi: Malaysian Journal of Communication, 33(2), 89-104.

An, S. K., \& Gower, K. K. (2009). How do the news media frame crises? A content analysis of crisis news coverage. Public Relations Review, 35(2), 107-112.

Arandas, M. F., Chang, P. K., Mohamad, E., \& Idid, S. A. (2019). Framing the first Palestinian general elections by Malaysia's New Straits Times. Jurnal Komunikasi: Malaysian Journal of Communication, 35(2), 141-158.

Baker, G. F. (2001). Race and reputation: Restoring image beyond the crisis. In Heath, R. (Ed.), Handbook of public relations (pp. 513-520). London: Sage publications.

Benoit, W. L. (1997a). Hugh Grant's image restoration discourse: An actor apologizes. Communication Quarterly, 45(3), 251-267.

Benoit, W. L. (1997b). Image repair discourse and crisis communication. Public Relations Review, 23(2), 177-186.

Benoit, W. L. (2000). Another visit to the theory of image restoration strategies. Communication Quarterly, 48(1), 40-43.

Benoit, W. L. (2006). President Bush's image repair effort on Meet the Press: The complexities of defeasibility. Journal of Applied Communication Research, 34(3), 285-306.

Benoit, W. L. (2013). Image repair theory and corporate reputation. In Carroll, C. E. (Ed.), The handbook of communication and corporate reputation (pp. 213-221). Malden: WileyBlackwell.

Benoit, W. L. (2014). President Barack Obama's image repair on HealthCare.gov. Public Relations Review, 40(5), 733-738.

Benoit, W. L., \& Anderson, K. K. (1996). Blending politics and entertainment: Dan Quayle versus Murphy Brown. Southern Journal of Communication, 62(1), 73-85.

Benoit, W. L., \& Czerwinski, A. (1997). A critical analysis of USAir's image repair discourse. Business Communication Quarterly, 60(3), 38-57.

Benoit, W. L., \& Drew, S. (1997). Appropriateness and effectiveness of image repair strategies. Communication Reports, 10(2), 153-163.

Boin, A., Hart, P. T., Stern, E., \& Sundelius, B. (2005). The politics of crisis management. New York: Cambridge University Press.

Brinson, S. L., \& Benoit, W. L. (1996). Dow Corning's image repair strategies in the breast implant crisis. Communication Quarterly 44(1), 29-41.

Bruenisholz, E., Wilson-Wilde, L., Ribaux, O., \& Delémont, O. (2019). Deliberate fires: From data to intelligence. Forensic science international, 301, 240-253.

Cheng, S. S., Padgett, D. R. G., \& Parekh, V. (2013). Crisis response across borders: A comparative study of two companies' image repair discourse. International Journal of Business and Social Science, 4(5), 124-135.

Chimbarange, A., Mukenge, C., \& Kombe, F. (2013). A linguistic analysis of Zimbabwean prime minister Morgan Tsvangirai's image repair discourse: Letter to the Zimbabwean public (30 November 2011). Global Journal of Human Social Science Research, 13(3), 1-7.

Cho, S. H., \& Gower, K. K. (2006). Framing effect on the public's response to crisis: Human interest frame and crisis type influencing responsibility and blame. Public Relations Review, 32(4), 420-422.

Chong, J. K. (2004). Six steps to better crisis management. Journal of Business Strategy, 25(2), 43-46. 
Coombs, W. T. (1998). An analytic framework for crisis situations: Better responses from a better understanding of the situation. Journal of Public Relations Research, 10(3), 177191.

Coombs, W. T. (2010). Parameters for crisis communication. In Coombs, W. T., \& Holladay, S. J. (Eds.), The handbook of crisis communication (pp. 17-53). Malden: Wiley-Blackwell.

Devlin, E. S. (2007). Crisis management planning and execution. NY: Auerbach Publications.

Elo, S., \& Kyngäs, H. (2008). The qualitative content analysis process. Journal of Advanced Nursing, 62(1), 107-115.

Fearn-Banks, K. (2011). Crisis communications: A casebook approach. London: Routledge.

Fener, T., \& Cevik, T. (2015). Leadership in crisis management: Separation of leadership and executive concepts. Procedia Economics and Finance, 26, 695-701.

Ferguson, D. P., Wallace, J. D., \& Chandler, R. C. (2012). Rehabilitating your organization's image: Public relations professionals' perceptions of the effectiveness and ethicality of image repair strategies in crisis situations. Public Relations Journal, 6(1), 1-19.

Ferguson, D. P., Wallace, J. D., \& Chandler, R. C. (2018). Hierarchical consistency of strategies in image repair theory: PR practitioners' perceptions of effective and preferred crisis communication strategies. Journal of Public Relations Research, 30(5-6), 251-272.

Flynn, T. T. (2005). Organizational crisis public relations management in Canada and the United States: Constructing a predictive model of crisis preparedness (Ph.D thesis, Syracuse University, ProQuest Dissertations and Theses).

Garcia, H. F. (2006). Effective leadership response to crisis. Strategy \& Leadership, 34, 4-10.

Greenberg, J., \& Elliott, C. (2009). A cold cut crisis: Listeriosis, maple leaf foods, and the politics of apology. Canadian Journal of Communication, 34(2), 189-204.

Grunig, J. E. (1993). Image and substance: From symbolic to behavioral relationships. Public Relations Review, 19(2), 121-139.

Harrison, G. A. (2005). Communication strategies as a basis for crisis management including use of the internet as a delivery platform (Ph.D thesis, Georgia State University, ProQuest Dissertations and Theses).

Heilmann, D. (2015). After Indonesia's ratification: The ASEAN agreement on transboundary haze pollution and its effectiveness as a regional environmental governance tool. Journal of Current Southeast Asian Affairs, 34(3), 95-121.

Lee, M., Neeley, G., \& Stewart, K. (Eds.). (2011). The practice of government public relations. London: CRC Press.

Macnamara, J. R. (2005). Media content analysis: Its uses, benefits and best practice methodology. Asia Pacific Public Relations Journal, 6(1), 1-23.

Marra, F. J. (1992). Crisis public relations: A theoretical model (Ph.D thesis. University of Maryland College Park, ProQuest Dissertations and Theses).

Masduki, (2015). Crisis communication a comparative analysis of brand recovery strategy between Malaysia airlines and Air Asia after the crash of MH370 and QZ8501. Paper presented at The International Conference on Social Science Research, Kuala Lumpur (pp. 340-350).

Morris, T., \& Goldsworthy, S. (2008). Public relations for the new Europe. London: Palgrave Macmillan.

Moser, S. C. (2010). Communicating climate change: History, challenges, process and future directions. Wiley Interdisciplinary Reviews: Climate Change, 1(1), 31-53. 
Purworini, D., Purnamasari, D., \& Hartuti, D. P. (2019). Crisis communication in a natural disaster: A chaos theory approach. Jurnal Komunikasi: Malaysian Journal of Communication, 35(2), 35-48.

Roberts, G. F. (2006). Image restoration theory: An empirical study of corporate apology tactics employed by the US air force academy (MA thesis, University of South Florida, Graduate Theses and Dissertations).

Saleh, R. (2019). Emergency response and communication during Bili-Bili dam flood crisis in Indonesia. Jurnal Komunikasi: Malaysian Journal of Communication, 35(4), 484-497.

Schäfer, M. S. (2012). Online communication on climate change and climate politics: A literature review. Wiley Interdisciplinary Reviews: Climate Change, 3(6), 527-543.

Seeger, M. W., Sellnow, T. L., \& Ulmer, R. R. (2001). Public relations and crisis communication: Organizing and chaos. In Heath, R. (Ed.), Handbook of Public Relations (pp. 155-166). London: Sage publications.

Sellnow, T. L., \& Seeger, M. W. (2013). Theorizing crisis communication. Chichester: Wiley-Blackwell.

Sellnow, T. L., Seeger, M. W., \& Ulmer, R. R. (2002). Chaos theory, informational needs, and natural disasters. Journal of Applied Communication Research, 30(4), 269-292.

Selzer, J. H. (2013). Pay for play: Analysis of the image restoration strategies of high profile college athletes. Elon Journal of Undergraduate Research in Communications, 4(2), 16 32.

Sheldon, C. (2006). Image repair on the political front: An experiment testing effects of communication strategy and performance history in a political faux pas (Master thesis, University of Georgia, Athens).

Shiang, L. S., Chibundu, I. S., \& Wilson, S. (2020). Media coverage of Malaysian airline flight $\mathrm{MH} 370$ : A preliminary study on the framing of the crisis in the Malaysian mainstream and alternative newspapers. Jurnal Komunikasi: Malaysian Journal of Communication, 36(1), 90-108.

Strömbäck, J., \& Kiousis, S. (2011). Political public relations: Principles and applications. New York: Routledge.

Sunchindah, A. (2015). Transboundary haze pollution problem in Southeast Asia: Reframing ASEAN's response. Jakarta: Economic Research Institute for ASEAN and East Asia.

Tan, S. T., Hashim, H., Hoo, P. Y., Rashid, A. H. A., Lim, J. S., \& Ho, W. S. (2017). Mitigation the transboundary haze in ASEAN country: biomass to energy GHG emission assessment. Energy Procedia, 105, 1178-1183.

Tench, R., \& Yeomans, L. (2006). Exploring public relations. London: Pearson Education.

United Nations Framework Convention on Climate Change. (2007). Climate change: Impacts, vulnerabilities and adaptation in developing countries. Bonn, Germany: Author.

Wartick, S. L. (2002). Measuring corporate reputation: Definition and data. Business \& Society, 41(4), 371-392.

Wright, C. (2009). Responding to crises: A test of the situational crisis communication theory (Graduate Theses and Dissertations, University of South Florida, United States).

Yusof, K., Azid, A., Samsudin, M. S., \& Jamalani, M. A. (2017). An overview of transboundary haze studies: The underlying causes and regional disputes on Southeast Asia region. Malaysian Journal of Fundamental and Applied Sciences, 13(4), 747-753.

Zappala, J. M., \& Carden, A. R. (2004). Public relations worktext: A writing and planning resource. London: Lawrence Erlbaum Associates. 